\title{
Seroprevalence of hepatitis A among children of different socioeconomic status in Cairo
}

\author{
I.I. Salama, ${ }^{1}$ S.M. Samy, ${ }^{2}$ F.A. Shaaban,${ }^{2}$ A.I. Hassanin ${ }^{2}$ and L.A. Abou Ismail ${ }^{3}$
}



ABSTRACT To determine seroprevalence of anti-hepatitis A virus (HAV) antibodies and potential risk factors for and age of contracting symptomatic hepatitis A infection among children of different socioeconomic status (SES) in Cairo, we carried out a cross-sectional study on 426 children aged 3-18 years from low SES areas and 142 from high SES areas. Seroprevalence was significantly higher with age. Seropositivity to anti-HAV antibodies was significantly higher among children of low and very low SES, $90 \%$, compared to children of high SES, $50 \%$. Water supply and sewage disposal were the most significant risk factors for HAV seropositivity in children of low SES. Children of high SES were more likely to be vulnerable to infection in adolescence than those of low SES.

La séroprévalence de l'hépatite A chez les enfants issus de différents milieux socio-économiques au Caire

RÉSUMÉ Afin de déterminer la séroprévalence des anticorps anti-VHA (VHA = virus de l'hépatite A), les facteurs de risque potentiels de développement de l'hépatite $A$ et l'âge de manifestation de l'infection chez les enfants issus de différents milieux socio-économiques au Caire, nous avons mené une étude transversale auprès de 426 enfants âgés de 3 à 18 ans de zones socio-économiquement défavorisées et de 142 enfants de zones socio-économiquement favorisées. Il a été constaté une augmentation significative de la séroprévalence proportionnelle à l'âge. La séropositivité pour les anticorps anti-VHA s'est avérée très élevée chez les enfants des milieux défavorisés et très défavorisés, s'élevant chez ceux-ci à $90 \%$ contre $50 \%$ dans les classes plus favorisées. Les conditions d'alimentation en eau et d'évacuation des eaux usées se sont imposées comme les facteurs de risque majeurs de séropositivité VHA chez les enfants de milieux défavorisés. Les enfants issus des classes plus favorisées sont apparus plus vulnérables à cette infection à l'adolescence que ceux appartenant aux milieux socio-économiquement faibles.

${ }^{1}$ Department of Community Medicine Research; ${ }^{2}$ Department of Child Health; ${ }^{3}$ Department of Clinical and Chemical Pathology, National Research Centre, Cairo, Egypt (Correspondence to F.A. Shaaban: fatmashaaban123@hotmail.com).

المجلة الصحية لشرق المتو سط، منظمة الصحة العالمة، المجلد الثالث عشر، العدد Y، V . Y. 


\section{Introduction}

Viral hepatitis, which causes various forms of acute and chronic liver disease, presents a public health problem worldwide. Hepatitis A virus (HAV) is an enterically transmitted viral infection, endemic in many developing countries, where the prevalence can approach $100 \%$ in children by 5 years of age [1]. Most infections in children younger than this are asymptomatic or have mild, nonspecific manifestations (e.g. fever) that are indistinguishable from other viral infections. With increasing age symptomatic acute infection is more common; chronic HAV infection does not occur [2].

Seroprevalence of HAV infection varies from one country to another according to socioeconomic factors and standard of living. In the developing countries, HAV is acquired very early in life and nearly $100 \%$ of adults have detectable levels of anti-HAV and are therefore immune to infection. In such countries, epidemics of HAV are uncommon [3]. In the more developed countries, where there is good sanitation and hygiene, most people reach adulthood without experiencing infection. It is characterized by a low prevalence among children $(10 \%)$, and a large susceptible pool of adults being negative for anti-HAV (about 63\%) [4].

In the United States of America, because children account for at least one third of cases and are also a potential source of infection for others, routine vaccination of children is an effective way of reducing hepatitis A incidence [5]. Highly effective vaccines against hepatitis $\mathrm{A}$ have been available since the mid 1990s, but vaccination is expensive and there are numerous reports worldwide on the changing epidemiology of hepatitis A and its prevalence. Therefore, information on the prevalence of immunity in each population would be required for any national hepatitis vaccination programme [6].

In Egypt, which is considered an area of high endemicity for HAV infection, marked economic, hygiene, and sanitary improvements have taken place in recent years, especially in urban areas [7]. Improvements in living conditions may lead to changes in the epidemiology of HAV infection, with a decrease in antibody prevalence among children; consequently a significant proportion of the adolescent and adult population will be at risk of infection [8].

The aim of the present study was to assess the difference in the seroprevalence of anti-HAV antibodies and the age of symptomatic HAV infection among children of different socioeconomic status in Cairo, Egypt. We also aimed to identify potential risk factors for seropositivity for anti-HAV antibodies.

\section{Methods}

This was a cross-sectional study carried out in the Health Insurance Clinic at El Abasseya, Cairo during the 6 month period October 2003-March 2004. The clinic serves several areas, mainly of low SES. Approval from the General Institute of Health Insurance was taken to allow the researchers to conduct the study and to collect blood from the participants. All students referred to the health insurance services for further examination for minor medical problems (school accidents, falls, cuts, headache, pallor, problems in visual acuity, etc.) were asked to participate in this study. The clinic is one of the paediatric clinics of the General Institute of Health Insurance (Ministry of Health and Population). It serves schoolchildren referred from public schools in the area. Therefore the participants are representative of the school population in urban

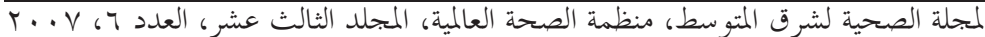


and semi-urban areas. For younger children, parent's consent for taking a blood sample was taken; for those aged 11 years and over, consent was obtained from both the parent and the child. There were 10 refusals to participate and 2 children who had already been vaccinated against hepatitis A were excluded.

All children aged 3-18 years, consecutively attending the Health Insurance Clinic during the study period were invited to participate in the study without any selection. Children who attended more than once during the study period were included only once. Parents of young children were interviewed by a member of the research team, while adolescents were personally interviewed, in the presence of their parents, to complete a questionnaire to collect demographic data (age, sex, residence, level of education, number of family members, SES, etc.), home sanitary conditions (source of drinking water, sewage disposal, etc.) and previous history of symptomatic hepatitis A (history of jaundice, confirmed by elevated liver enzymes and positive antibody test).

Socioeconomic status (SES) was determined according to the scale of Fahmy and El-Sherbiny [9]; 7 items were assessed to categorize SES of the children into very low, low, middle and high. These items were: mother's education, father's education, family income, family size, water supply, refuse disposal and sewage disposal [9].

Residence was divided into 4 regions based on level of environmental sanitation and source of water supply: region 1: Hadaek El Kobbah and surrounding areas; region 2: Misr El Kademah and El Moneib; region 3: Mansheyet Nasser and El Duekah; region 4: Ain Shams and surrounding areas.

To compare between the children of low SES and children of high SES as regards the prevalence and age symptomatic of HAV infection, 142 children of high SES, children of physicians working in the National Research Centre, of comparable age and sex were also studied.

Blood was drawn aseptically by venepuncture by a physician in the outpatients' laboratory (clinical and chemical pathology) at the General Institute of Health Insurance. The serum was separated by centrifugation at $2000 \mathrm{rpm}$ for 20 minutes; serum was stored at $-20^{\circ} \mathrm{C}$ until examined for determination of antibodies to HAV using competitive enzyme immunoassay commercial kits (Dia.Pro Diagnostic Bioprobes Srl, Milan, Italy). This is a solid phase sandwich enzyme (linked immunosorbent assay) [10]. Liver enzyme alanine aminotransferase (ALT) level was evaluated to assess liver function by a kinetic method (ELITech Diagnostic Kit, SEPPIM, Sees, France) $[11]$.

Data entry and analysis were done using SPSS, version 9. Statistical analysis of the results was made by applying the chisquared test of significance.

The association between potential risk factors and past infection with HAV was evaluated using backward logistic regression analysis. Goodness-of-fit statistics were examined to determine appropriateness of the final models. Risk factors entered in the logistic analysis included age, sex, housing conditions and socioeconomic variables to detect the most significant predictive risk factors associated with HAV seropositivity.

\section{Results}

Among the children who participated from the Health Insurance Clinic, seroprevalence of anti-HAV antibodies was $86.2 \%$ overall, $85.3 \%$ among males and $86.9 \%$ females with no statistically significant difference 
$(P>0.05)$. In the high SES group (children of physicians), overall prevalence of antiHAV antibodies was $50.2 \%$, also with no significant difference between males and females.

A significantly higher prevalence of anti-HAV in relation to age was observed in the low SES children, $64.3 \%$ among those $<6$ years, $85.3 \%$ among those aged $6-10$ years, and $90.0 \%$ among older children $(\geq 11$ years $)(P<0.05)$.

The relations between prevalence of anti-HAV antibodies and socioeconomic characteristics and sanitary housing conditions among the participants from the Health Insurance Clinic are shown in Table 2 . There was a statistically significant association with education of parents: seroprevalence of anti-HAV antibodies was higher for children whose parents were educated to preparatory level or below $(P$

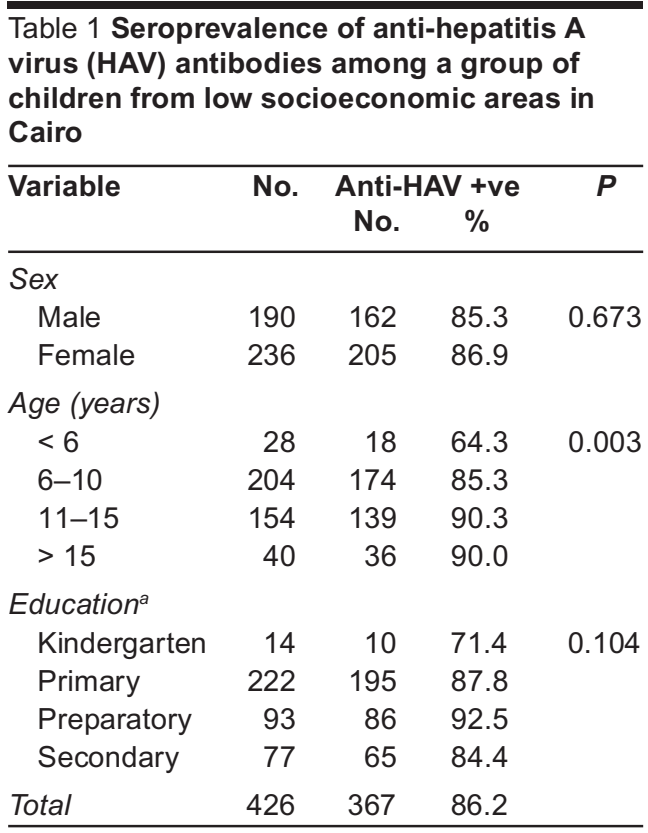

${ }^{a} 20$ children $<6$ years old were not registered in kindergarten and stayed home with their mothers.
$<0.05)$. There was also a statistically significant association between HAV seropositivity and socioeconomic status $(P<0.01)$. A higher proportion of children from the very low social level were HAV positive (91.7\%) compared to the other social levels (Table 2). A higher prevalence of anti-HAV $(90.0 \%)$ was also found among children living in slum areas (areas with non-hygienic water supply, sewage disposal and refuse disposal) compared to areas with a safe water supply and basic sanitation (77.6\%) $(P<0.01)$. There was a significant regional (based on sanitation and water supply) variation in the anti-HAV prevalence, it was lowest $(73.2 \%)$ in region 1 and highest (95.8\%) in region $4(P<0.001)$.

Among the $367 \mathrm{HAV}$-seropositive children participating from the Health Insurance Clinic, 33 had had symptomatic disease. At the time of the study, 6 children had acute hepatitis with elevated serum ALT (range 74-422 U/L). Table 3 shows no significant statistical difference in the seroprevalence of HAV antibodies between children with a history of jaundice or contact with a jaundiced patient and those without $(P>0.05)$. Excluding the 6 cases with acute infection, there was no significant difference in mean ALT levels among children positive for $(9.7$ $\mathrm{U} / \mathrm{L}$; standard deviation 4.5) and negative for (9.5 U/L; standard deviation 5.5) HAV IgG antibodies $(P>0.05)$.

From multiple logistic analysis, water supply and sewage disposal were the most important risk factors for prediction of HAV seropositivity among the participants from the Health Insurance Clinic. The risk of infection with HAV was 3 times higher among children using a public water supply compared to those with piped water inside the home. Using non-hygienic sewage disposal increased the risk of HAV infection 2.6-fold compared to using a private toilet with flush (Table 4).

المجلة الصحية لشرق المتوسط، منظمة الصحة العالمية، المجلد الثالث عشر، العدد Y، V... 
Table 2 Seroprevalence of anti-hepatitis A virus (HAV) antibodies among a group of children in Cairo according to socioeconomic variables

\begin{tabular}{|c|c|c|c|c|}
\hline \multirow[t]{2}{*}{ Variable } & \multirow{2}{*}{$\begin{array}{c}\text { Total } \\
(n=426)\end{array}$} & \multicolumn{2}{|c|}{ Anti-HAV +ve } & \multirow[t]{2}{*}{$P$} \\
\hline & & No. & $\%$ & \\
\hline \multicolumn{5}{|l|}{ Mother's education } \\
\hline Preparatory and below & 357 & 313 & 87.7 & 0.036 \\
\hline Secondary and above & 69 & 54 & 78.3 & \\
\hline \multicolumn{5}{|l|}{ Father's education } \\
\hline Preparatory and below & 338 & 301 & 85.0 & 0.002 \\
\hline Secondary and above & 88 & 67 & 76.1 & \\
\hline \multicolumn{5}{|l|}{ Monthly family income } \\
\hline \multicolumn{5}{|l|}{ (Egyptian pounds) } \\
\hline$<300$ & 297 & 265 & 89.2 & 0.005 \\
\hline$\geq 300$ & 129 & 102 & 79.1 & \\
\hline \multicolumn{5}{|l|}{ Family size } \\
\hline 3-5 persons & 206 & 172 & 83.4 & 0.278 \\
\hline$\geq 6$ persons & 220 & 195 & 88.6 & \\
\hline \multicolumn{5}{|l|}{ Environment } \\
\hline Slum & 274 & 249 & 90.9 & $<0.001$ \\
\hline Urban & 152 & 118 & 77.6 & \\
\hline \multicolumn{5}{|l|}{ Water supply } \\
\hline Outside house & 90 & 86 & 95.6 & 0.004 \\
\hline Inside house & 336 & 281 & 83.6 & \\
\hline \multicolumn{5}{|l|}{ Refuse disposal } \\
\hline Non-hygienic & 89 & 83 & 93.3 & 0.028 \\
\hline Hygienic & 337 & 284 & 84.2 & \\
\hline \multicolumn{5}{|l|}{ Sewage disposal } \\
\hline Non hygienic & 274 & 249 & 90.8 & $<0.001$ \\
\hline Private toilet with flush & 152 & 118 & 77.6 & \\
\hline \multicolumn{5}{|l|}{ Residence $^{a}$} \\
\hline Region 1 & 83 & 61 & 73.5 & $<0.001$ \\
\hline Region 2 & 19 & 16 & 84.2 & \\
\hline Region 3 & 300 & 267 & 89.0 & \\
\hline Region 4 & 24 & 23 & 95.8 & \\
\hline \multicolumn{5}{|l|}{ SES } \\
\hline Very low & 223 & 204 & 91.7 & 0.003 \\
\hline Low & 144 & 118 & 81.9 & \\
\hline Middle & 47 & 37 & 78.7 & \\
\hline High & 12 & 7 & 58.3 & \\
\hline \multicolumn{5}{|c|}{$\begin{array}{l}\text { Region 1: Hadaek El Kobbah and surrounding areas. Region 2: Misr El } \\
\text { Kademah and El Moneib, Region 3: Mansheyet Nasser and El Duekah. } \\
\text { Region 4: Ain Shams and surrounding areas. } \\
\text { SES = socioeconomic status, determined according to Fahmy and } \\
\text { Sherbiny [10]. }\end{array}$} \\
\hline
\end{tabular}




\begin{tabular}{|c|c|c|c|c|c|}
\hline \multirow[t]{2}{*}{ Variable } & \multicolumn{2}{|c|}{ Total $(n=367)$} & \multicolumn{2}{|c|}{ Anti-HAV +ve } & \multirow[t]{2}{*}{$P$} \\
\hline & No. & & & $\%$ & \\
\hline \multicolumn{6}{|c|}{ History of jaundice } \\
\hline Yes & 35 & 8.2 & 33 & 94.3 & 0.210 \\
\hline No & 391 & 91.8 & 334 & 85.4 & \\
\hline \multicolumn{6}{|c|}{$\begin{array}{l}\text { Contact with } \\
\text { jaundiced persons }\end{array}$} \\
\hline Yes & 86 & 20.2 & 77 & 89.5 & 0.476 \\
\hline No & 340 & 79.8 & 290 & 85.3 & \\
\hline \multicolumn{6}{|c|}{ Serum ALT (IU/L) } \\
\hline$>42$ & 6 & 1.4 & 6 & 100.0 & 0.941 \\
\hline$<42$ & 420 & 98.6 & 361 & 85.9 & \\
\hline
\end{tabular}

$A L T=$ alanine transaminase.

Table 5 shows the comparison between the children of very low and low SES (from the Health Insurance Clinic) and those from high SES (142 children of physicians from the National Research Centre). Seroprevalence of HAV antibodies was significantly lower among children of high SES (50.7\%) than among those of very low and low SES $(87.7 \%)(P<0.01)$. The proportion of children with history of symptomatic

Table 4 Multiple logistic analysis identifying risk factors significantly predictive of hepatitis A virus seropositivity

\begin{tabular}{lcc}
\hline Predictive variable & $\begin{array}{c}\text { Adjusted } \\
\text { OR }\end{array}$ & $\mathbf{9 5 \%} \mathbf{~ C l}$ \\
\hline $\begin{array}{l}\text { Water supply } \\
\text { Inside house }\end{array}$ & $\mathrm{R}$ & \\
$\quad$ Outside house & $3.0^{* *}$ & $1.1-10.2$ \\
Sewage & & \\
$\quad$ Private toilet with flush & $\mathrm{R}$ & \\
$\quad$ Non hygienic disposal & $2.6^{*}$ & $1.4-4.8$ \\
\hline${ }^{*} \mathrm{P}<0.05$. & & \\
${ }^{* * P}<0.01$. & \\
$O R=$ odds ratio; $\mathrm{Cl}=$ confidence interval. \\
$R=$ reference group.
\end{tabular}

HAV infection contracted at 10 years of age or older was significantly higher among children of high SES than among those of very low and low SES $(P<0.05)$. They also reported having more severe symptoms compared to younger children

\section{Discussion}

Results of the present study were compared with previous HAV seroprevalence studies done in Egypt [12-16]. Direct comparison between these studies is difficult because different age strata and geographical distribution were studied. However, the overall seroprevalence of hepatitis $\mathrm{A}$ in all the previous studies ranges between $89.4 \%$ (in Alexandria) and 100\% (in rural areas). In the present study, although the overall prevalence of anti-HAV was still very high $(86.2 \%)$ it was slightly lower than in the previous studies. A similar high prevalence has been reported from Palestine (93.3\%) and Syria $(89 \%)[17,18]$. Intermediate prevalence of $52.4 \%$ has been recorded in Saudi Arabia [19]. 


\begin{tabular}{|c|c|c|c|c|c|c|c|}
\hline \multirow[t]{2}{*}{ Variable } & $\begin{array}{r}\text { Soc } \\
\text { Very Ic } \\
(n=\end{array}$ & $\begin{array}{l}\text { economi } \\
v \& \text { low } \\
367) \\
\%\end{array}$ & $\begin{array}{r}\text { ic st } \\
\text { Hic } \\
(n=\end{array}$ & $\begin{array}{l}\text { tus } \\
\mathrm{h}^{\mathrm{a}} \\
142) \\
0 /\end{array}$ & \multirow[t]{2}{*}{ OR } & \multirow[t]{2}{*}{$95 \% \mathrm{Cl}$} & \multirow[t]{2}{*}{$P^{b}$} \\
\hline & & & & & & & \\
\hline \multicolumn{8}{|c|}{ HAV seroprevalence } \\
\hline$+v e$ & 322 & 87.7 & 72 & 50.7 & 6.9 & $4.3-11.2$ & $<0.001$ \\
\hline$-v e$ & 45 & 12.3 & 70 & 49.3 & & & \\
\hline \multicolumn{8}{|c|}{$\begin{array}{l}\text { History of symptomatic HAV } \\
\text { infection, age contracted (years) }\end{array}$} \\
\hline$<10$ & 18 & 75.0 & 4 & 33.3 & 6.0 & $1.1-37.2$ & 0.028 \\
\hline$\geq 10$ & 6 & 25.0 & 8 & 66.7 & & & \\
\hline
\end{tabular}

Higher prevalence of anti-HAV in relation to age was observed in this study. A much higher prevalence was reported among preschool children in India $(90.9 \%)$ [20]. Therefore, in out study, almost $10 \%$ of the low SES urban children over the age of 10 years in were still vulnerable to HAV infection. This is expected to be much higher among children of high SES, and in fact around $50 \%$ of children from the high SES group in our study were not immune and would be vulnerable to infection in early adulthood. This is in accordance with the expected pattern of HAV seroprevalence in a region of high endemicity $[8,18]$.

In the current study, no statistically significant difference was observed between the seroprevalence of anti-HAV among males and females and this was in accordance with some studies in India $[8,20]$; in Latin America and South Africa, however, anti-HAV seroprevalence was significantly higher in females than males $[21,22]$.

Similar to the present study, in a Palestinian study a significant association was found between seroprevalence of anti-HAV and socioeconomic standard and family income: it was significantly lower in children of high SES and those from families with higher income [17]. In the present study there was a significant relationship between HAV seroprevalence and sanitary conditions: prevalence rates were higher among children living in poor sanitary conditions and water supply and sewage disposal were the most important significant risk factors for the prediction of HAV seropositivity. This is in accordance with studies done in Saudi Arabia and in Santiago [23,24].

Regional variation was observed in the current study, as very high prevalence of anti-HAV was found in the region of Ain Shams and surrounding areas $(95.8 \%)$ compared to Hadaek El Kobbah and surrounding areas $(73.2 \%)$. This could be explained in part by the diversity in standards for environmental hygiene and safety of water supply, despite the homogeneity of the population regarding cultural practices and habits: for example, region 4 has many slum areas with poor sanitary conditions compared to region 1 which has a piped household water supply and hygienic sewage disposal. Similar observations were made in a study done in Saudi Arabia [23]. 
A higher prevalence of anti-HAV antibodies was noted with greater family size but it was not statistically significant. However, Fix et al. found a significant association between the prevalence of anti-HAV antibodies and crowded living situations [24]. The present study as well as other studies revealed that lower levels of maternal or paternal education were significantly associated with a higher seroprevalence [24].

A history of hepatitis or of contact with a case of hepatitis has been shown to be associated with anti-HAV seropositivity [19]. In the present study no statistically significant association was found. Regarding children who had history of symptomatic HAV infection, most contracted the infection before 10 years of age but more than $20 \%$ contracted the infection at age $\geq 10$ years. While more than $80 \%$ of cases of hepatitis A occurring in children under 5 years of age are asymptomatic, infected children without jaundice can still shed the virus and serve as a source of infection for others [25]. Tosun et al. reported a shift of seropositivity from children to adolescents in Turkey, especially in families with average or high
SES [26]. In the present study the majority of low SES children who gave a history of symptomatic HAV infection were under 10 years of age while for children of high SES the majority who gave history of symptomatic infection were aged $\geq 10$ years Children who got symptomatic infection above age of 10 years reported severe form of symptoms compared to younger children. Similarly, Arguedas and Fallon reported that the severity of HAV illness increases with age [27].

To sum up, despite improvements in gross national products and in socioeconomic standards [28], Egypt is still highly endemic for HAV infection, especially among those living in a low SES with poor housing conditions. While, nearly half of the studied children of high SES were susceptible to hepatitis A infection (nonimmune). Raising the socioeconomic standard of the population, improving housing conditions and improving sanitary conditions are needed for these low SES regions. Further studies are needed for high SES children to assess their need for HAV vaccination.

\section{References}

1. Poovorawan $Y$, Chatchatee $P$, Chongsrisawat $V$. Epidemiology and prophylaxis of viral hepatitis: a global perspective. Journal of gastroenterology \& hepatology, 2002, 17(suppl.):S155-66.

2. Joshi N, Yr NK, Kumar A. Age related seroprevalence of antibodies to hepatitis A virus in Hyderabad, India. Tropical gastroenterology, 2000, 21(2):63-5.

3. Gust ID, Feinstone SM. Hepatitis A. In: Popper H, Schaffner F, eds. Progress in liver diseases. Philadelphia, WB Saunders Co., 1988:371-8.

4. Marsano LS. Hepatitis. Primary care: clinics in office practice, 2003, 30(1):81-107.

5. Bardenheier B et al. Parental knowledge, attitudes, and practices associated with not receiving hepatitis $A$ vaccine in a demonstration project in Butte County, California. Pediatrics, 2003, 112(4):e269.

6. Levy I et al. Hepatitis A virus seroprevalence in 1000 university students in Toronto. Canada communicable disease report, 2001, 27(11):93-6.

7. El-Zanaty F, Way AA. Egypt demographic and health survey 2000. Calverton, Maryland, USA, Ministry of Health \& Population, Egypt, National Population Council and ORC Macro, 2001.

8. Mall ML et al. Seroepidemiology of hepatitis A infection in India: changing pattern. Indian journal of gastroenterology, 2001, $20(4): 132-5$.

المجلة الصحية لشرق المتوسط، منظمة الصحة العالمية، المجلد الثالث عشر، العدد Y، V... 
9. Fahmy SI, El-Sherbiny AF. Determining simple parameters for social classifications for health research. Bulletin of the High Institute of Public Health, 1985, 13(5):95-108.

10. Bower WA et al. Duration of viremia in naturally-acquired hepatitis $A$ viral infections. Journal of infectious diseases, 2000, 182(1):12-7.

11. Expert panel on enzyme of the IFCC. Clinica chimica acta, 1976, 70:F19.

12. El-Zimaity DM et al. Acute sporadic hepatitis in an Egyptian pediatric population. American journal of tropical medicine \& hygiene, 1993, 48(3):372-6.

13. Samy AM, Farid AM, Zohair N. Serological markers of hepatitis $A$ and $B$ in Bedouin population of north Sinai, Egypt. Bulletin of Alexandria Faculty of Medicine, 1989, 25(3):781-7.

14. Kamel MA et al. Seroepidemiology of hepatitis $E$ virus in the Nile Delta. Journal of medical virology, 1995, 47(4):399-403.

15. Darwish MA et al. High seroprevalence of hepatitis $A, B, C$ and $E$ viruses in residents in an Egyptian village in the Nile Delta, a pilot study. American journal of tropical medicine \& hygiene, 1996, 54(6):554-8.

16. Zaytoun SS. Immunity status against HAV among school children in Alexandria [MSc thesis]. Alexandria, Department of Paediatrics, University of Alexandria, 2003.

17. Yassin $\mathrm{K}$ et al. The epidemiology of hepatitis A infection in Palestine: a universal vaccination programme is not yet needed. Epidemiology and infection, 2001, 127(2):335-9.

18. Antaki N, Kebbewar MK. Hepatitis A seroprevalence rate in Syria. Tropical doctor, 2000, 30(2):99-101.

19. Khalil $M$ et al. Childhood epidemiology of hepatitis A virus in Riyadh, Saudi Ara- bia. Annals of Saudi medicine, 1998, 18(1):18-21.

20. Das $\mathrm{K}$ et al. The changing epidemiology pattern of hepatitis A in an urban population of India: emergence of a trend similar to the European countries. European journal of epidemiology, 2000, 16(6):507-10.

21. Tanaka J. Hepatitis A shifting epidemiology in Latin America. Vaccine, 2000, 18(suppl. 1):S57-60.

22. Vardas E et al. Viral hepatitis in South Africa health care workers at increased risk of occupational exposure to bloodborne viruses. Journal of hospital infection, 2002, 50(1):6-12.

23. Al Rashed RS. Prevalence of hepatitis A virus among Saudi Arabian children: a community-based study. Annals of Saudi medicine, 1997, 17(2):200-3.

24. Fix $A D$ et al. Age-specific prevalence of antibodies to hepatitis A in Santiago, Chile: risk factors and shift in age of infection among children and young adults. American journal of tropical medicine \& hygiene, 2002, 66(5):628-32.

25. Gendrel D. Vaccination contre hépatite A chez l'enfant [Hepatitis A vaccination in children]. Medecine tropicale, 2004, 64(4):394-400.

26. Tosun $S$ et al. Changes in seroprevalence of hepatitis A in children and adolescents in Manisa, Turkey. Pediatrics international, 2004, 46(6):669-72.

27. Arguedas MR, Fallon MB. Hepatitis A. Current treatment options in gastroenterology, 2004 7(6):443-50.

28. El-Zanaty F, Way AA. Egypt interim demographic and health survey, 2003. Cairo, Ministry of Health and Population, 2004. 